\title{
Sprinkler Evaporation Losses in Alfalfa during Solid-set Sprinkler Irrigation in Semi Arid Areas
}

\begin{tabular}{|c|l|}
\hline \multirow{2}{*}{ Complete List of Authors: } & Irrigation Science \\
\cline { 2 - 3 } & \\
\hline & Original Paper \\
\hline & $\begin{array}{l}\text { STAMBOULI, TALEL; The Agrifood Research and Technology Center of } \\
\text { Aragón (CITA-DGA), Soil and Irrigation } \\
\text { Martínez-Cob, Antonio; Estación Experimental Aula Dei, Consejo Superior } \\
\text { de Investigaciones Científicas (EEAD-CSIC), Agua y Suelo } \\
\text { Faci, José Maria; The Agri-Food Research and Technology Centre of Aragón } \\
\text { (CITA-DGA), Suelos y Riegos } \\
\text { Howell, Terry; Conservation and Production Research Laboratory (CPRL- } \\
\text { ARS-USDA), Soil and Water Resources Management Unit } \\
\text { Zapata, Nery; Estación Experimental Aula Dei, Consejo Superior de } \\
\text { Investigaciones Científicas (EEAD-CSIC), Agua y Suelo }\end{array}$ \\
\hline
\end{tabular}




\title{
Sprinkler Evaporation Losses in Alfalfa during Solid-set Sprinkler Irrigation in Semi Arid Areas
}

\begin{abstract}
Gross sprinkler evaporation losses $\left(\mathrm{SEL} \mathrm{L}_{\mathrm{g}}\right.$ can be large and decrease irrigation application efficiency. However, it is not universally established how much of the SEL contributes to decrease the crop evapotranspiration during the sprinkler irrigation and how much are the net sprinkler losses (SELn). The components of SEL were the wind drift and evaporation losses (WDEL) and the water intercepted by the crop (IL). The gross WDEL (WDELg) and evapotranspiration (ET) were measured simultaneously in two alfalfa (Medicago sativa L.) plots, one being irrigated (moist, MT) and the other one not being irrigated (dry, DT). Catch can measurements, mass gains and losses in the lysimeters and micrometeorological measurements were performed to establish net WDEL (WDELn) during the irrigation and net IL $\left(\mathrm{IL}_{\mathrm{n}}\right)$ after the irrigation as the difference between $\mathrm{ET}_{\mathrm{MT}}$ and $\mathrm{ET}_{\mathrm{DT}}$. Also, equations to estimate $\mathrm{IL}_{n}$ and net sprinkler evaporation losses $\left(\mathrm{SEL}_{n}\right)$ were developed. $\mathrm{IL}_{n}$ was strongly related to vapor pressure deficit (VPD). SEL $n$ were $8.3 \%$ of the total applied water. During daytime irrigations, SELn was $9.8 \%$ of the irrigation water and slightly less than WDELg $(10.9 \%)$. During nighttime irrigations $\mathrm{SEL}_{\mathrm{n}}$ were slightly greater than $\mathrm{WDEL}_{\mathrm{g}}\left(5.4 \%\right.$ and $3.7 \%$, respectively). SEL $\mathrm{L}_{\mathrm{n}}$ was mainly a function of wind speed.
\end{abstract}

\section{KEY WORDS}

Gross wind drift and evaporation losses, Net wind drift and evaporation losses, Gross interception losses, Net interception losses, Gross Sprinkler evaporation losses, Net sprinkler evaporation losses, Weighing lysimeters, Day/night time irrigation, Microclimatic and Physiological changes. 


\section{ABREVIATIONS}

ai

AMRE = Average Magnitude of Relative Error

$\mathrm{CV}=$ Coefficient of variation

d1 = Large nozzle diameter $(\mathrm{mm})$

$\mathrm{d} 2=$ Small nozzle diameter $(\mathrm{mm})$

DC $\quad=$ Discharge coefficient $(=0.98)$

di $=$ During irrigation

DT = Dry treatment

$\mathrm{E}=$ Coefficient of Efficiency

$\mathrm{EF}$

EP

$\mathrm{ET}_{\mathrm{o}} \quad=$ Reference evapotranspiration $(\mathrm{mm})$

$\mathrm{ET}_{\mathrm{c}} \quad=$ Crop evapotranspiration $(\mathrm{mm})$

$\mathrm{ET}_{\mathrm{DT}}=$ Evapotranspiration rate of the dry treatment plot $\left(\mathrm{mm} \mathrm{h}^{-1}\right)$

$\mathrm{ET}_{\mathrm{MT}}=$ Evapotranspiration rate of the moist treatment plot $\left(\mathrm{mm} \mathrm{h}^{-1}\right)$

$\mathrm{g}=$ Gravity acceleration $\left(\mathrm{m} \mathrm{s}^{-2}\right)$

$\mathrm{H} \quad$ = Nozzle height $(\mathrm{m})$

$\mathrm{I}_{\mathrm{cc}} \quad=$ Irrigation depth collected in the catch can $(\mathrm{mm})$

$\mathrm{I}_{\mathrm{g}} \quad$ = Gross irrigation depth $(\mathrm{mm})$

$\mathrm{I}_{\mathrm{lcc}} \quad=$ Irrigation depth collected in the lysimeter $(\mathrm{mm})$

$\mathrm{I}_{\mathrm{lq}} \quad=$ Irrigation application for the lowest quarter of the field (mm)

$\mathrm{I}_{\mathrm{lys}} \quad=$ irrigation depth recorded by the lysimeter $(\mathrm{mm})$

IL $\quad=$ Intercepted losses $(\%$ or $\mathrm{mm})$

$\mathrm{IL}_{\mathrm{g}}=$ Gross Intercepted losses (\% or $\left.\mathrm{mm}\right)$

$\mathrm{IL}_{\mathrm{n}} \quad=$ Net interception losses $(\%$ or $\mathrm{mm})$

IS $\quad=$ Similarity Index

$\mathrm{k}=$ Total Irrigation duration (hours)

$\mathrm{K}_{\mathrm{c}} \quad=$ Crop coefficient

MAE = Mean average error

MSE $\quad=$ Mean square error

$\mathrm{m}=$ = Time after irrigation event considered to compute the $\mathrm{IL}_{\mathrm{n}}$ (hours) 
2 


\section{INTRODUCTION}

Irrigation has an important role to increase and stabilize the crop yield, while the application efficiency is important when selecting a suitable irrigation method and scheduling in arid and semi-arid regions. A fraction of the water applied by the sprinkler nozzles is lost by evaporation before reaching the soil during sprinkler irrigation events. These sprinkler evaporation losses (SEL) can be divided in wind drift and evaporation losses (WDEL) and interception losses (IL).

$$
S E L=W D E L+I L
$$

WDEL represent the water lost during the travel of the water droplets from the sprinkler nozzle to the surface being irrigated. Some of these losses drift away from the irrigated area. Nevertheless, all this water is eventually lost to evaporation. Some water droplets reach the crop leaves and stems but evaporate before reaching the soil surface. These latter losses represent the IL.

Previous works have reported different values and predictive models for WDEL depending upon different experimental conditions: sprinkler spacing, operating pressure, nozzle diameter, and, particularly, meteorological conditions (wind speed, water vapor pressure deficit and temperature) (Yazar, 1984; Tarjuelo et al., 2000). Edling (1985) and Thompson et al. (1993a) found that WDEL were inversely proportional to the diameter of the droplets which in turn depend, among others, on nozzle diameter and nozzle operating pressure (Kohl and Wright 1974; Solomon et al. 1985). Lorenzini (2004) and De Wrachien and Lorenzini (2006) indicated that evaporation losses were directly proportional to droplet diameter considering the effects of air friction (ignored in previous models) on droplet evaporation which is 
relevant under the turbulent flow commonly found at the boundary layer. Thus, values of WDEL up to 30 to $50 \%$ of the applied water have been reported in the Middle Ebro River Valley located in the north-eastern of Spain (Playán et al., 2005). Wind speed and, to a lesser extent, relative humidity have been found to be the most important meteorological factors affecting WDEL (Playán et al. 2005).

By the other hand, IL depends on the water storage capacity of a crop which in turn depends on its architecture. Several authors have reported IL values for maize (Zea mays L.) of about 2.5 to $2.7 \mathrm{~mm}$ (Fritschen, 1960; Seginer, 1967; Smajstrla and Hanson, 1980; Norman and Campbell, 1983; Steiner et al., 1983a). Lamm and Manges (2000) estimated an average value of IL of $1.8 \mathrm{~mm}$. For sprinkler irrigation, IL is quantitatively smaller than WDEL, particularly for long irrigation events, as typical solid-set sprinkler irrigation depths range between 10 to $50 \mathrm{~mm}$.

Due to the water lost to evaporation, the crop microclimate changes during and just after sprinkler irrigation, i.e. the air temperature $(\mathrm{T})$ and the vapor pressure deficit (VPD) decrease (Robinson 1970; Steiner et al. 1983b; Tolk et al. 1995). For maize, this microclimate change only last a few hours after the irrigation event (Tolk et al., 1995; Cavero et al., 2009). The decline in the VPD, during and after sprinkler irrigation, would lead to a certain reduction of the crop transpiration rate. This would result in the conservation of soil water which would otherwise be depleted by the crop (McNaughton, 1981; Steiner et al., 1983a). Assessment of the effect of sprinkler irrigation on soil evaporation $(E)$ is more difficult. The increase in soil water and the presence of ponded water on the soil surface could result in an increased potential for evaporation. However, the reduction in the evaporative demand of the 
air, due to the reduction of VPD, will induce a decrease in the evaporation flux. Nevertheless, the ratio of soil evaporation to crop evapotranspiration $(E T=E+T)$ in fully developed canopies is low.

Following McNaughton (1981), any reduction in crop ET from a wetted surface (compared to that from a dry area not being irrigated simultaneously but kept under similar water availability conditions) can be subtracted from the gross irrigation water losses to estimate the net irrigation water losses. At first glance, SEL are considered consumptive, non-beneficial water use (Burt et al., 1997). However, the part of SEL replacing crop ET should be regarded as consumptive and beneficial (McNaughton, 1981). This results in the introduction of gross and net sprinkler evaporation losses (SELg and SELn). Eq. (1) is valid for both gross and net losses. Taking into account net evaporation losses instead of gross evaporation losses could lead to an increase of application efficiency for a given application depth (MartínezCob et al. 2008).

The differences in ET rates between wet and dry surfaces just after irrigation events have been the object of several studies. Similar ET rates for both wet and dry crops have been reported by McMillan and Burgy (1960), Frost (1963), and Seginer (1967). Waggoner et al. (1969) reported short-term ET rates of wet maize canopies more than twice that of dry maize canopies during the typical summertime conditions in Connecticut (USA). This difference only lasted for about 15 minutes, after which the ET rates became similar for both canopies. Less information is available regarding to the differences in ET rates between wet and dry surfaces during the irrigation events themselves. Frost and Schwalen (1960) found that dry- 
leaf ET equaled or exceeded wet-leaf ET (both measured by weighing lysimeters) under similar atmospheric conditions. Sternberg (1967) reported that rye-grass ET (also measured by weighing lysimeters) was almost suppressed during irrigation and decreased by about $33 \%$ after irrigation, as compared to that of a non irrigated lysimeter. They found a 36-41\% reduction of maize transpiration during two daytime irrigation events using a lateral move sprinkler irrigation system in Texas (USA). Tolk et al. (1995) used an energy balance based method to quantify evaporation rates and net irrigation water depth. What these authors called interception losses were likely reflecting total SEL rather than IL because the energy balance as applied by Tolk et al. (1995) would not allow separating WDEL from IL. Martínez-Cob et al. (2008) analyzed 21 irrigation events and found average reductions of maize transpiration of $58 \%$, and ET of 32-55\% for wet surfaces during daytime solid-set sprinkler irrigation events. After the irrigation events, the average reduction of maize transpiration was about $20 \%$, while ET for the wet surface was about $35 \%$ higher than that of the dry surface, reflecting the net interception losses $\left(I L_{n}\right)$ just after the irrigation events. Those differences between the wet and dry surfaces only lasted about 1 to $2 \mathrm{~h}$ after the irrigation. Nevertheless, the ILn only amounted $1 \%$ of the applied water. During the irrigation event, the observed sharp decrease of VPD leads to a lower water vapour gradient between the evaporating surface and the atmosphere layer next to it (Martinez-Cob et al., 2008). The ratio of canopy to aerodynamic resistances is also low, so that the reduction of transpiration almost voids the increased evaporation of intercepted water (Monteith 1981; Steiner 
et al. 1983a). For these reasons, interception losses during irrigation time were small enough to be considered as negligible (Martinez-Cob et al., 2008).

No much information is available on the possible reduction of alfalfa (Medicago sativa L.) ET during and after sprinkler irrigation. There is some evidence of the possible influence of the wettability of leaves on the gas exchange of different crops under sprinkler irrigation. Thus Cavero et al. (2010) reported a different wettability of maize and alfalfa leaves affecting the change of net photosynthesis rates during solidset sprinkler irrigation. This different wettability of alfalfa leaves may also have an influence on the reduction of alfalfa ET rates due to the irrigation as compared to the previously reported reductions of maize ET. Subsequently, the contribution of alfalfa ET reduction during and after sprinkler irrigation to application efficiency could be somewhat different to that reported for maize. Thus the general objective of this paper was to quantify the net sprinkler evaporation losses $\left(S E L_{n}\right)$ for the alfalfa crop and its components. This objective will be reached through the following specific objectives:

- Analysis of the meteorological (air temperature, relative humidity and vapor pressure deficit) and physiological changes (canopy temperature) in alfalfa during and after solid-set sprinkler irrigation.

- Characterization of the alfalfa ET before, during and after sprinkler irrigation as compared to that occurring at the same time in an alfalfa crop not being irrigated at that moment. 
- Evaluation of the gross WDEL (WDELg) and estimation of the net WDEL $\left(W L_{n}\right)$ when the contribution of the alfalfa ET reduction during and after irrigation is taken into account.

- Estimation and modeling of the net interception losses (ILn) for alfalfa.

- Quantification and modeling of the sprinkler evaporation losses (SELn). 


\section{MATERIAL AND METHODS}

\section{General characteristics of the experiments}

This research was conducted during the 2009 irrigation season (March-October) at a 2.0 ha field located in Montañana (Zaragoza, NE Spain). Geographical coordinates are $41^{\circ} 43^{\prime} \mathrm{N}$ latitude and $0^{\circ} 49^{\prime} \mathrm{W}$ longitude, and the elevation is $225 \mathrm{~m}$ above the sea level. The crop was alfalfa. The field was divided in two plots of 1.0 ha each, plots A and $\mathrm{B}$. The available water holding capacity within the top $1.2 \mathrm{~m}$ of the soil profile in these plots was $0.173 \mathrm{~m}^{3} \mathrm{~m}^{-3}$. The soil is classified as Typic Xerofluvent, with a sandy loam texture, mixed (calcareous), and mesic (Soil Survey Staff 1999).

The climate is semiarid Mediterranean. The mean annual values of several meteorological variables are: air temperature, $14^{\circ} \mathrm{C}\left(24.2^{\circ} \mathrm{C}\right.$ for July and $4.8{ }^{\circ} \mathrm{C}$ for December); precipitation, $340 \mathrm{~mm}$; reference evapotranspiration $\left(\mathrm{ET}_{\mathrm{o}}\right), 1,230 \mathrm{~mm}$. The predominant wind directions are northwest (locally denominated Cierzo, dry and cold) and southeast (locally denominated Bochorno, dry and hot) with an annual average wind speed (2-m above ground level) of $2.3 \mathrm{~m} \mathrm{~s}^{-1}$, classified as moderate wind (Martínez-Cob et al. 2010).

A solid-set sprinkler irrigation with a square spacing of $15 \mathrm{~m} \times 15 \mathrm{~m}$ was installed in the 2 ha experimental plot (Figure 1). Impact sprinklers (RC-130 model Riegos Costa, Lleida, Spain $\left.{ }^{1}\right)$ were used. These sprinklers had nozzle diameters of $4.4 \mathrm{~mm}$

\footnotetext{
${ }^{1}$ The use of trade, firm, or corporation names in this article is for the information and convenience of the reader. Such use does not constitute an official endorsement or approval by the CITA-DGA or the CSIC or the ARS-USDA of any product or service to the exclusion of others that may be suitable.
} 
and $2.4 \mathrm{~mm}$, a vertical throw angle of $25^{\circ}$, and the nozzle height was located at $2.2 \mathrm{~m}$ above the ground. Irrigation pressure was measured every $5 \mathrm{~min}$ during each irrigation event by two pressure transducers (Model 2200/2600, Gems Basingstoke, Hampshire, United Kingdom), one in each plot, located in the sprinkler riser pipe at $2.2 \mathrm{~m}$ above the ground (Figure 1). The working pressure $(\mathrm{P}, \mathrm{kPa})$ measured by the transducers was used to calculate the gross irrigation depth $\left(\mathrm{I}_{\mathrm{g}}, \mathrm{mm}\right)$ using the following equation based on the Torricelli's Theorem and the Orifice Equation (Norman et al. 1990):

$$
I_{g}=\frac{\left[0.00035 \pi D_{C} \sqrt{P}\left(d_{1}^{2}+d_{2}^{2}\right)\right] t}{S}
$$

where $\mathrm{D}_{\mathrm{C}}$ is the discharge coefficient $\left(\mathrm{D}_{\mathrm{C}}=0.98\right.$ as determined experimentally by Playán et al. 2006); $d_{1}, d_{2}$ are the large and small nozzle diameter, respectively, mm; $t$ is the irrigation event duration, $\mathrm{s}$; and $\mathrm{S}$ is the area irrigated by one sprinkler, $\mathrm{m}^{2}$ (in this experiment, equal to $15 \mathrm{~m} \times 15 \mathrm{~m}=225 \mathrm{~m}^{2}$ ). The application rate for this sprinkler layout working at a pressure of $300 \mathrm{kPa}$ was $7.5 \mathrm{~mm} \mathrm{~h}^{-1}$. For the evaluated irrigations the rate varies according to the working pressure and the irrigation time.

Irrigations were scheduled to meet the crop water requirements, which were computed weekly from reference evapotranspiration $\left(\mathrm{ET}_{\mathrm{o}}\right)$ estimates and local crop coefficients. Daily $\mathrm{ET}_{\mathrm{o}}$ was computed using the FAO Penman-Monteith method (Allen et al. 1998) from the daily meteorological values (air temperature and relative humidity, wind speed and global solar radiation) recorded at a standard automatic weather station located at a grass plot ('grass weather station'), adjacent (northern side) to plot A. Local crop coefficients were derived from tabulated values (Allen et 
al. 1998) adapted according to local phenological and meteorological data (MartínezCob 2004). Weekly crop water requirements were converted to weekly crop irrigation requirements (NIR, $\mathrm{mm}$ ) using the following expression:

$$
\mathrm{N} I R=\frac{K_{c} E T_{0}-E P}{E F_{a p l}}
$$

where EP was effective precipitation, $\mathrm{mm}$, estimated as $75 \%$ of recorded precipitation (Dastane 1978); and $\mathrm{EF}_{\mathrm{apl}}$ is water application efficiency estimated as $80 \%$ for the solid-set sprinkler irrigation (Clemmens and Dedrick 1994).

A weekly irrigation schedule was established according to NIR such that each plot was irrigated 2 or 3 times per week not exceeding 4 h per irrigation event $(\sim 30$ $\mathrm{mm}$ per event) to avoid soil saturation. The irrigation was alternated between plots, so when a plot was irrigated (moist treatment, MT), the second plot was not irrigated (dry treatment, DT). However, both plots were fully irrigated covering the alfalfa water requirements, and both plots received approximately the same seasonal irrigation depth. Once one plot was irrigated, the other plot was irrigated approximately 8 hours later to ensure that the microclimate effects were totally removed (Cavero et al. 2009).

\section{Water Loss Calculations}

Following ASAE.S.398.1 (1985), the sprinkler irrigation performance was evaluated by the gross WDEL (WDELg, \%). WDELg were measured using a network of 25 plastic catch cans (at a spacing of $3 \mathrm{~m} \mathrm{X} 3 \mathrm{~m}$ ) that was arranged within four sprinklers in each plot (Figure 1). Catch can (own manufacture) were conical in its 
lower part (100 mm length) and cylindrical in its upper part (200 mm length). The diameter of the upper part was $160 \mathrm{~mm}$. The catch cans were marked in $\mathrm{mm}$ for direct readout up to $45 \mathrm{~mm}$. Catch cans were placed at $0.4 \mathrm{~m}$ above the ground just after each alfalfa clipping and at $0.85 \mathrm{~m}$ once the alfalfa crop reached a full development to ensure the catch cans were always above the alfalfa canopy. WDELg (\%) was estimated as the percentage of water delivered by sprinklers $\left(I_{g}, \mathrm{~mm}\right)$ and not collected within catch cans or collectors $\left(\mathrm{I}_{\mathrm{cc}}, \mathrm{mm}\right)$ (Dechmi et al. 2003; Playán et al. 2005; and Sánchez et al. 2010a). $I_{c c}$ was the average of the water collected at the 25 catch cans.

$$
W D E L_{g}=\frac{\left(I_{g}-I_{c c}\right)}{I_{g}} \times 100
$$

Alfalfa evapotranspiration at each subplot was measured by a weighing lysimeter located at the middle of each subplot (Figure 1). Each lysimeter had an effective surface area of $6.26 \mathrm{~m}^{2}$ (length $2.72 \mathrm{~m} \times$ width $2.30 \mathrm{~m}$, both measured up to the midpoint of the inner-outer wall). Lysimeter depth was $1.7 \mathrm{~m}$. Both lysimeters were made of stainless steel with a thickness of $6 \mathrm{~mm}$. A more detailed description of the lysimeters is presented in Martínez-Cob (2001). Lysimeters recorded 5-min evapotranspiration (ET) rates that were combined into hourly totals from the $2 \mathrm{~h}$ before to the $3 \mathrm{~h}$ after each irrigation event. During the irrigation event, 5-min ET rates recorded at the dry treatment lysimeter $\left(\mathrm{ET}_{\mathrm{DT}}\right)$ were summed and later converted to $\mathrm{mm} \mathrm{h}^{-1}$. However, it was impossible to directly measure ET rates during the irrigation event at the moist treatment lysimeter $\left(\mathrm{ET}_{\mathrm{MT}}\right)$ due to its gain of mass 
because of the applied irrigation water. Thus, the $\mathrm{ET}_{\mathrm{MT}}$ rates during the irrigation event were determined as follows (Martínez-Cob et al. 2008):

$$
E T_{M T_{-} d i}=\frac{I_{l c c}-I_{l y s}}{t}
$$

where: $\mathrm{ET}_{\mathrm{MT} \_\mathrm{di}}$ is the estimated $\mathrm{ET}$ rate at the moist treatment during the irrigation event, $\mathrm{mm} \mathrm{h}^{-1} ; I_{l c c}$ is the water depth applied to the lysimeter during the irrigation event, $\mathrm{mm}$; $I_{l y s}$ is the water depth recorded at the lysimeter during the irrigation event, $\mathrm{mm}$; and $t$, duration of the irrigation event, $\mathrm{h}$. $I_{l c c}$ was determined as the average water depth collected in 18 catch cans (Figure 1), similar to those used for measurement of $\mathrm{WDEL}_{\mathrm{g}}$, located just around the lysimeter, a few centimeters apart from the outer wall of the lysimeter tank. The $I_{l y s}$ was determined as the gain in mass by the lysimeter during the irrigation event divided by its effective surface area (Martínez-Cob 2001). Uncertainty of Eqn. (5) arises from the different resolution of the catch cans and the lysimeter, about 0.5 and $0.05 \mathrm{~mm}$, respectively.

Martínez-Cob et al. (2008) reported that maize ET reduced by about 32-55 \% on average during irrigation events while maize transpiration reduced by about $58 \%$ on average. This difference in the percent reduction of both variables was due to the evaporation of intercepted water at the soil and crop surfaces during the irrigation. In other words, the estimated values of $\mathrm{ET}_{\mathrm{MT} \_\mathrm{di}}$ also include the evaporation of the intercepted water during the irrigation. For impact sprinklers, the magnitude of the evaporation of the intercepted water at the soil should be relatively negligible (Yonts, 2000) and the evaporation of the intercepted water at the crop surfaces will also be 
relatively small due to the reduction of VPD (Steiner et al., 1983a; Thompson et al., 1996; Schneider and Howell, 1995).

The ET rates of the different irrigation events at both moist and dry treatments were compared for the two periods ( 1 and $2 \mathrm{~h}$ ) before, during, and three periods ( 1 to $3 \mathrm{~h}$ ) after the irrigation events. A Student t-test for paired samples was performed to test the null hypothesis that the difference between averages ET at both treatments was equal to $0(\alpha=0.05)$. The t-test was applied for each of the six abovementioned periods.

As previously mentioned, part of the WDELg replaces crop ET during the irrigation events. Then, the work hypothesis is that the reduction of crop ET (i.e., the difference between $\mathrm{ET}_{\mathrm{DT}}$ and $\mathrm{ET}_{\mathrm{MT}}$ during the irrigation events) can be subtracted from WDELg to get the net WDEL. Therefore:

$$
W D E L_{n}=W D E L_{g}-\sum_{i=0}^{t}\left(E T_{D T}-E T_{M T}\right)_{d i}
$$

where: WDELn are the net wind drift and evaporation losses, $\mathrm{mm} ; \mathrm{t}$ is the total irrigation duration, $\mathrm{h}$; and $\left(\mathrm{ET}_{\mathrm{DT}}-\mathrm{ET}_{\mathrm{MT}}\right)_{\mathrm{di}}$ is the reduction of $\mathrm{ET}$ during the irrigation event (di), $\mathrm{mm} \mathrm{h}^{-1}$.

After the irrigation, the crop transpiration of the wetted surface continues to be reduced for some time (Martínez-Cob et al., 2008). But that reduction is less after irrigation than during the irrigation event (as it occurs for VPD reduction) so transpiration reduction is lower than the evaporation of intercepted water. Then, the difference between $\mathrm{ET}_{\mathrm{MT}}$ and $\mathrm{ET}_{\mathrm{DT}}$ after the irrigation should represent the net 
interception losses, i.e. the difference between the gross interception losses and the reduction of transpiration after the irrigation. Thus, after the irrigation event (ai), and during the time it takes for this water to evaporate, the following equation holds (Martínez-Cob et al. 2008):

$$
I L_{n}=\sum_{i=0}^{m}\left(E T_{M T}-E T_{D T}\right)_{a i}
$$

where: $\mathrm{IL}_{\mathrm{n}}$ are the net intercepted losses, $\mathrm{mm}$; $\mathrm{m}$ is the time duration after irrigation used to calculate the $\mathrm{IL}_{n}, \mathrm{~h}$. The time after irrigation (ai) considered for the $\mathrm{IL}_{\mathrm{n}}$ calculation corresponded to the time needed to equal $\mathrm{ET}_{\mathrm{MT}}$ and $\mathrm{ET}_{\mathrm{DT}}$ (i.e. until the irrigated canopy was dry). Values of $\mathrm{WDEL}_{n}$ and $\mathrm{IL}_{n}$ were used to determine $\mathrm{SEL}_{\mathrm{n}}$ applying Eq. (1).

\section{Prediction of net sprinkler evaporation losses}

Statistical analyses of prediction equations of WDELg, IL $_{n}$ and SEL $n$ as a function of several meteorological variables: VPD, wind speed $(\mathrm{U})$, solar radiation $\left(\mathrm{R}_{\mathrm{sol}}\right)$, and air temperature $\left(\mathrm{T}_{\text {air }}\right)$ were performed using the Statgraphics Plus software (version 5.0, Statistical Graphic Corp. 1994-2000). The equations were selected through a backward stepwise procedure accounting for their statistical indicators used to monitor and compare the selected equations (Dolado, 1990): the adjusted coefficient of determination (adjusted $\mathrm{R}^{2}$ ), the mean square error (MSE), the coefficient of efficiency (E) defined by Wilcox et al. (1990), the similarity index (IS) (Willmott, 1981) and the root mean square error (RMSE). Two additional statistics were introduced to evaluate the predictive capability of the equations: the average magnitude of the relative error (AMRE, \%) and the prediction level 25 (Pred [0.25]) (Dolado, 1999). The 
Pred [0.25] is the percentage of the estimated values differing from the measured value by less than 25\% (Dalado, 1990 and Playán et al., 2005).

\section{Microclimatic changes}

An automatic weather station was installed in the center of each plot, next to the weighing lysimeters (Figure 1). Each station had a datalogger (Campbell Scientific model CR10X, Shepshed, Loughborough, U.K.) monitoring an air temperature and relative humidity probe (Vaisala model HMP45AC, Helsinki, Finland) and an infrared thermometer (Apogee Instruments Inc., Roseville, CA, USA) at $0.1 \mathrm{~Hz}$ (10 s). The temperature and relative humidity probe was installed at $1.5 \mathrm{~m}$ above ground; its accuracy was $\pm 0.3^{\circ} \mathrm{C}$ for temperature and $\pm 3 \%$ for relative humidity. The infrared thermometer was located at $1.0 \mathrm{~m}$ above the crop canopy with an angle of $45^{\circ}$ and was oriented towards the north; its accuracy is $\pm 0.3^{\circ} \mathrm{C}$. Averages of air temperature and relative humidity were computed for each 5-min period, and 30-min averages of canopy temperature were computed and stored in the Datalogger memory. VPD was computed for each 5-min period using the 5-min averages of air temperature and relative humidity as described by Allen et al. (1998).

Values of air temperature, VPD and canopy temperature at both treatments were compared for the periods before ( 1 and $2 \mathrm{~h}$ ), during and after ( 1 to $3 \mathrm{~h}$ ) the irrigation events. As for ET, the Student t-test for paired samples was used (Devore and Peck, 1986). 


\section{RESULTS AND DISCUSSION}

\section{General characteristics of the experiments}

The total irrigation depth applied in the 2009 irrigation season for alfalfa was 798 $\mathrm{mm}$ and $813 \mathrm{~mm}$ for plots $\mathrm{A}$ and $\mathrm{B}$, respectively. This slight difference was due to the slightly greater irrigation pressure in the plot B (308 kPa) than that in the plot A (302 $\mathrm{kPa}$ ). The total number of irrigation events for the entire irrigation season was the same for both plots (42 events); minimum, maximum and average irrigation durations were $1.0 \mathrm{~h}, 4.0 \mathrm{~h}$ and $2.5 \mathrm{~h}$, respectively.

A total of 24 daytime irrigation events (12 at plot A and 12 at plot B) and 12 nighttime irrigation events (6 at plot $\mathrm{A}$ and 6 at plot $\mathrm{B}$ ) were evaluated for WDEL $\mathrm{W}_{\mathrm{g}}$ microclimatic and ET changes before, during and after irrigation, WDEL $L_{n}$ and SEL . Table 1 summarizes the general characteristics of the evaluated irrigation events. The average applied irrigation water per event was $21.1 \mathrm{~mm}$ and $20.8 \mathrm{~mm}$ for daytime and nighttime irrigation, respectively.

Distinct general meteorological conditions occurred during daytime and nighttime irrigation events according to the recorded values at the 'grass station' (Table 1). The average wind speed (U) during daytime irrigation $\left(2.5 \mathrm{~m} \mathrm{~s}^{-1}\right)$ was twice that recorded during the nighttime events $\left(1.2 \mathrm{~m} \mathrm{~s}^{-1}\right)$. The maximum wind speeds were $5.8 \mathrm{~m} \mathrm{~s}^{-1}$ and $3.1 \mathrm{~m} \mathrm{~s}^{-1}$ during daytime and nighttime irrigations, respectively. The mean air temperature and VPD were $24.4^{\circ} \mathrm{C}$ and $1.47 \mathrm{kPa}$, respectively, for 
daytime irrigations, while they were $14.8^{\circ} \mathrm{C}$ and $0.28 \mathrm{kPa}$, respectively, for nighttime irrigations.

\section{Microclimatic and physiological changes during sprinkler irrigation}

Microclimatic and physiological changes started immediately at the beginning of the irrigation events, more pronounced in the case of daytime events (Figure 2). This agrees with the results reported by Tolk et al. (1995), Thompson et al. (1993b), and Cavero et al. (2009). During daytime irrigation events, a significant $(\alpha=0.05)$ decrease in air temperature $(\mathrm{T})$ was observed for the moist treatment regarding to the dry treatment (Figure 2). On average, this temperature decrease due to sprinkler irrigation was $1.5^{\circ} \mathrm{C}$. This decrease in temperature for the moist treatment remained significant (although less in magnitude, about $0.6^{\circ} \mathrm{C}, 0.1^{\circ} \mathrm{C}$ and $0.1^{\circ} \mathrm{C}$ on average for one, two and three hours after irrigation events respectively) until three hours after the end of the irrigation. During nighttime irrigation events, air temperature $(\mathrm{T})$ of the moist treatment (MT) decreased also significantly $(\alpha=0.05)$ as compared with the dry treatment (DT), but this decrease was much lower $\left(0.4{ }^{\circ} \mathrm{C}\right.$ on average) (Figure 2$)$.

Similar behavior was observed for the vapor pressure deficit (VPD) and the canopy temperature. The average decrease of VPD in the moist treatment during the irrigation was $0.44 \mathrm{kPa}$ and $0.11 \mathrm{kPa}$ for the daytime and nighttime irrigation events, respectively. The canopy temperature in the moist treatment declined $3^{\circ} \mathrm{C}$ on average during daytime irrigation events, although, that decrease was negligible during nighttime irrigation events $\left(0.1^{\circ} \mathrm{C}\right)$.

After the irrigation event, the difference in the VPD above the crop canopy between the non-irrigated plot (DT) and the irrigated plot (MT) were also significant 
(although to a lesser extent) until 2 hours after daytime irrigation and up to 3 hours after the nighttime irrigation.

The canopy temperature follows the same pattern as the VPD; a significant difference was also detected up to $3 \mathrm{~h}$ after daytime irrigation events. This difference was decreasing as time advances.

The decrease in air temperature, VPD and canopy temperature above alfalfa was less than reported by Cavero et al. (2009) $1.0 \mathrm{~m}$ above the maize canopy. The VPD was measured at $1.5 \mathrm{~m}$ above ground level which implies an average height of measurements above the alfalfa canopy of $0.7 \mathrm{~m}$ to $1.3 \mathrm{~m}$. Differences in the meteorological conditions of the experiments, in the measurement height and in the density of both crops (maize and alfalfa) may partly explain the differences. Microclimatic and physiological changes lasted only 3 hours after irrigation at most. Other authors have also reported that microclimatic changes last for a short period of time after the irrigation (Cavero et al., 2009; Tolk et al., 1995).

Figure 3, shows the relationship between the 5 minutes averages of air temperature (T), alfalfa canopy temperature (TV) and VPD during the irrigation in the irrigated plot (MT) versus the corresponding averages recorded at the same time in the not irrigated plots (DT), for all evaluated irrigation events. Microclimatic and physiological changes were more pronounced during daytime irrigation (Figure 3 left) than during nighttime irrigation (Figure 3 right). Cavero et al. (2009) reported the same patterns for corn and stated that the differences were due to the largest temperature and VPD conditions for the daytime irrigations. 


\section{Sprinkler irrigation effects on crop evapotranspiration}

Figure 4 shows the average alfalfa ET rates for the moist treatment versus those for the dry treatment for the periods 1 and $2 \mathrm{~h}$ before, during, and 1 to $3 \mathrm{~h}$ after each daytime irrigation event. Likewise, the overall average values of $\mathrm{ET}_{\mathrm{MT}}$ and $\mathrm{ET}_{\mathrm{DT}}$ for alfalfa for the abovementioned periods are listed in Table 2 for day and nighttime irrigation events. There was no significant difference $(a=0.05)$ between the two treatments 1 or 2 hours before the irrigation event for both daytime and nighttime irrigations (Figure 4, Table 2). However, $\mathrm{ET}_{\mathrm{MT}}$ was significantly lower (about $42 \%$ on average) than $\mathrm{ET}_{\mathrm{DT}}$ during the daytime irrigation event (Table 2; Figure 4). This ET reduction in alfalfa (42\%) was lower than that reported for maize (55\%) by MartínezCob et al. (2008) when these authors used the same approach to that used in this study (Eq. 5) to determine the $\mathrm{ET}_{\mathrm{MT}}$

The differences on meteorological conditions between both experiments could partially explain the differences. For the alfalfa experiments the average air temperature $(\mathrm{T})$, VPD and wind speed $(\mathrm{U})$ were $24.4{ }^{\circ} \mathrm{C}, 1.47 \mathrm{kPa}$ and $2.5 \mathrm{~m} \mathrm{~s}^{-1}$, respectively, much lower than those reported by Martínez-Cob et al. (2008) for corn, $30.6^{\circ} \mathrm{C}, 3.0 \mathrm{kPa}$ and $3.0 \mathrm{~m} \mathrm{~s}^{-1}$, respectively. Cavero et al. (2010) reported a reduction on the rate of photosynthesis for maize by $23 \%$ during the sprinkler irrigation event. However, photosynthesis of alfalfa was slightly increased (not significantly) during the sprinkler irrigation event. These authors reported difference in leaf characteristics (contact angle of water and canopies) between maize and alfalfa. This different wettability of alfalfa leaves may also have an influence on the reduction of alfalfa ET rates due to the irrigation as compared to the previously reported reductions of maize ET. Consequently, the contribution of alfalfa ET reduction during and after 
sprinkler irrigation to application efficiency could be somewhat different to that reported for maize.

Sternberg (1967) used a weighing lysimeter to study rye grass ET during and after sprinkler irrigation events at Davis (California) and reported an almost complete suppression of ET during the irrigation and a reduction of about $33 \%$ after the irrigation. These different results can be attributed to the fact that Sternberg (1967) used always the same lysimeter as moist treatment, while the lysimeter for dry treatment recorded systematically higher ET values before the irrigation. The results of this study have shown that ET was not completely suppressed during the irrigation because the transpiration, the main component of ET, decreased but was not suppressed (Martínez-Cob et al., 2008). During nighttime irrigation events, the differences between treatments were also statistically significant but the overall average values of ET for both treatments were small (Table 2), within the precision of the lysimeter, so it could be assumed that the ET reduction during nighttime periods can be considered as negligible.

After the irrigation events, contrary to what was observed during irrigation, $\mathrm{ET}_{\mathrm{MT}}$ was significantly $\left(\mathrm{a}=0.05\right.$ ) greater (about 12.5 to $19 \%$ ) than $\mathrm{ET}_{\mathrm{DT}}$ (Figure 4 , after and Table 2). This increase of $\mathrm{ET}_{\mathrm{MT}}$ after the irrigation event was due to the evaporation of canopy intercepted water and to the lower transpiration reduction between the dry and the moist plot compared to that occurring during the irrigation event (Figure 4) (Tolk et al. 1995; Martínez-Cob et al., 2008). These highest ET rates for the moist treatment were only observed for the first hour after nighttime irrigation events, however, after the daytime irrigation events, these highest ET rates 
were observed for the three monitored hours. On average, the difference between $\mathrm{ET}_{\mathrm{MT}}$ and $\mathrm{ET}_{\mathrm{DT}} 1$ to $3 \mathrm{~h}$ after daytime irrigations was quite similar (both in absolute and relative values); this behavior being somewhat different from that reported for maize by Tolk et al. (1995) and Martínez-Cob et al. (2008) for which the differences between treatments lasted no more than 1 to $2 \mathrm{~h}$. This longer duration of the ET reduction after the irrigation was also likely due to the different meteorological conditions observed in this study (lower evaporative demand) and the earlier irrigation starting time that may affects the ET reduction (11:20 GMT in this study versus 14:00 GMT reported by Martínez-Cob et al., 2008).

Determination of net sprinkler evaporation losses

Table 3 summarizes the applied water, the WDELg, the reduction of ET during irrigation event, and the balance of sprinkler evaporation losses for the daytime and irrigation events evaluated in this work. The gross irrigation water applied $\left(\mathrm{I}_{\mathrm{g}}\right)$ for the 36 evaluated events was $757.4 \mathrm{~mm}$, and the measured WDELg was $64.6 \mathrm{~mm}, 8.5 \%$ of the total applied water. WDELn for both daytime $(6.6 \%$ of applied water $)$ and nighttime (3.0\% of applied water) irrigation events were smaller than WDELg for those two periods, $10.9 \%$ and $3.7 \%$ of applied water, respectively, due to the contribution of ET reduction during the irrigation events. The ET reduction observed in this study for daytime irrigations was $21.6 \mathrm{~mm}$ (4.3\% of applied water), a value slightly lower than the $4.8 \%$ reported for maize by Martínez-Cob et al. (2008). Nighttime ET reduction ( $0.8 \%$ of applied water) was similar to that reported by Martínez-Cob et al. (2008). Total nighttime irrigated alfalfa ET is as much as $12 \%$ of the total daily (24-h) alfalfa ET due to the lower VPD and U during nighttime periods 
(Tolk et al., 2006). For this reason, nighttime ET reduction was extremely low. However, the WDELn reported by Martínez-Cob et al. (2008) were higher than those observed in this study. This was due to the higher WDELg values reported by Martínez-Cob et al. (2008) for both daytime and nighttime irrigations; in this study, average daytime WDELg was $10.9 \%$ while it was $19 \%$ in the research found by Martínez-Cob et al. (2008). The different average wind conditions for the two studies, $2.4 \mathrm{~m} \mathrm{~s}^{-1}$ in this study and $3.0 \mathrm{~m} \mathrm{~s}^{-1}$ in the study of Martínez-Cob et al. (2008), as well as differences in canopy height and architecture (Sánchez et al., 2010b) explained these different WDELg values.

Net interception losses (ILn) 1-3 h after the irrigation events were larger for daytime irrigation $(15.9 \mathrm{~mm}, 3.1 \%$ of the daytime applied water) than for nighttime irrigation $(6.0 \mathrm{~mm}, 2.4 \%$ of the nighttime applied water). When considering all the irrigation events, $\mathrm{IL}_{\mathrm{n}}$ for alfalfa resulted in $2.9 \%$ of the total applied water, greater than the $1.1 \%$ ILn reported by Martínez-Cob et al. (2008) for maize. Since ILn includes water on leaf and stem surfaces and water trapped in the leaf sheath area, the variation in ILn between crops can only be partially attributed to differences in crop architecture and characteristics of the leaf sheath of both crops. The higher ILn value found in this work was mainly due to the fact that the differences on ET between dry and moist lysimeters remained significant until 3 hours after the irrigation for the daytime irrigation events of the alfalfa crop (Table 2), i.e. more time than that reported for maize, likely due to the different meteorological conditions observed in this and the work of Martínez-Cob et al. (2008). 
Adding $\mathrm{IL}_{n}$ to $\mathrm{WDEL}_{\mathrm{n}}$ resulted in $\mathrm{SEL}_{\mathrm{n}}$ of $62.9 \mathrm{~mm}$ (8.3\% of applied water) when considering all the irrigation events (Table 3). For daytime irrigations, SEL were $_{n} 9.5$ $\mathrm{mm}$ (9.8 \% of applied water), while for nighttime irrigations, SEL were $13.4 \mathrm{~mm}$ (5.4 $\%$ of applied water) (Table 3). The difference between WDEL $_{g}$ and SEL for daytime irrigation represented $1.1 \%$ of the total applied water, lower than reported by Martínez-Cob et al. (2008) for maize (1.8\%), due to the higher wind speed and evaporative demand reported by these authors, also theses differences would be partially explained by the differences in crops height and architecture between maize and alfalfa.

For nighttime irrigation events, the almost negligible reduction of ET rates added to the $\mathrm{IL}_{\mathrm{n}}$ led to a higher average $S E L_{n}$ value compared to the average WDELg value, being the average difference between them of $1.7 \%$ of applied water. Similar results were found by Martínez-Cob et al. (2008) for maize nighttime irrigations (a difference of $1.5 \%$ of applied water between WDELg and $\left.S E L_{n}\right)$. The WDEL $L_{g}$ has been traditionally used in sprinkler irrigation engineering because of its experimental determination simplicity as an irrigation performance variable to characterize the adequacy of an irrigation event or schedule. However, the SEL $\mathrm{n}$ represents a more adequate variable to characterize the sprinkler losses. The SEL $n$ values for daytime

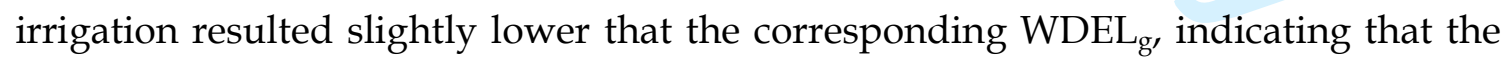
sprinkler application efficiency was slightly higher $(1.1 \%$ for alfalfa and $1.8 \%$ for maize crop) than that could be derived using the traditional variable, WDELg. On the other hand, for nighttime irrigation events, $\mathrm{SEL}_{\mathrm{n}}$ values resulted slightly higher than the corresponding WDEL $\mathrm{W}_{\mathrm{g}}$ indicating that the sprinkler application efficiency was 
slightly lower (1.7\% for alfalfa and $1.5 \%$ for maize) than that could be derived using the traditional variable, WDELg. These results should be taken into account in irrigation scheduling.

Figure 5 shows the measured $\mathrm{IL}_{\mathrm{n}}$ values for all irrigation events (daytime and nighttime) versus the average VPD recorded after the irrigation period. The selected equation presented in Figure 5 was a linear regression model that describes the positive relationship between the independent variable VPD and ILn. The increase in the evaporative demand of the air, due to the increase in VPD, will induce an important increase in the evaporation flux from the alfalfa intercepted water. This relationship established for alfalfa $\mathrm{IL}_{\mathrm{n}}$ was not established for maize in Martinez-Cob et al. (2008). The different wettability of maize and alfalfa leaves can explain the different role of VPD on alfalfa and maize $\mathrm{IL}_{n}$. A relatively moderate adjusted coefficient of determination was obtained for the $I_{n}$ equation $\left(R^{2}{ }_{a d j}=0.47\right)$. The relationship depicted on Figure 5 shows the best suited equation obtained by backward stepwise method to predict the ILn according to its explicative and predictive capabilities and its statistical significance (a lower than 0.01 ). The mean absolute error (MAE) for this equation was very low, less than $0.001 \%$, the coefficient of efficiency (E) and the Similarity Index (IS) were 0.65 and 0.89 respectively and very close to 1.0 presenting a better agreement between observed and predicted ILn $_{n}$ values. The Pred [0.25] indicates that the $45 \%$ of the predicted $I_{n}$ differed from the measured ILn by less than $25 \%$.

The best suited equation obtained to predict WDELn uses the wind speed as the explicative variable (statistical significance $a=0.01$ ) (Figure 6). The wind speed 
has also been reported by other authors (Playán et al., 2005; Zapata et al., 2007; Sánchez et al., 2011) as the most significant variable affecting the WDELg. A relatively moderate adjusted coefficient of determination was obtained $\left(\mathrm{R}^{2}\right.$ adj $\left.=0.41\right)$.

Wind speed also resulted the only significant variable $(\alpha=0.01)$ explaining the SEL $L_{n}$ variability $\left(\mathrm{R}^{2}{ }_{\mathrm{adj}}=0.44\right)$. MAE, IS, E and Pred [0.25] were $0.02,0.81$ and $0.48,60 \%$ respectively. The relationship between SELn and U was also found by Martinez-Cob et al. (2008) for maize. For conditions similar to those of this study, the regression equation obtained for all irrigation events to predict SEL $L_{n}$ as a function of $U$ would be recommended.

Although the relationship is significant between both WDELn and $U$ and between SELn and $U$, considerable variability in SELn and WDELn for the same wind speed was shown in Fig.6. This variability may be partially explained by the variability in other meteorological variables (such as $\mathrm{T}, \mathrm{RH}$, and VPD) that did not improve significantly the prediction equations and were excluded by the backward or stepwise statistical procedure.

Several researches found that interception losses ranged from 1.8 to $2.7 \mathrm{~mm}$ for maize (Steiner et al., 1983b; Seginer, 1967; Smajstrla and Hanson, 1980; Lamm and Manges, 2000) and more than $10 \mathrm{~mm}$ for winter wheat under high evaporation condition (Du et al., 2001; Li and Rao, 2000). Tolk et al. (1995) found maize intercepted losses less than $8 \%$ of the total water applied by impact sprinkler irrigation in day time, while Li and Rao (2000) found intercepted losses for winter wheat of $24-28 \%$ of the total seasonal applied water. Thompson et al. (1993a, b) used 
a equation to calculate the net interception losses, which amounted less than $1 \%$ of total applied water, less than the average $\operatorname{IL}_{n}(2.9 \%)$ in this study. However, the uncertainty of the net interception losses estimated by the model of Thompson et al. (1993a) was relatively high. The differences in crops architecture and measurement methodologies complicate the comparison between results obtained from the literature. 


\section{CONCLUSIONS}

Significant decreases of air temperature, VPD and canopy temperature were observed during daytime and nighttime sprinkler irrigations of alfalfa lasting up to 1 to $3 \mathrm{~h}$ after the irrigation events. Those decreases during daytime irrigation events were $1.5^{\circ} \mathrm{C}, 0.44 \mathrm{kPa}$ and $3.0^{\circ} \mathrm{C}$ on average, respectively.

During the irrigation events there was a significant reduction of ET for the moist treatment compared to the dry treatment. The average reduction was much higher for daytime irrigation events $\left(0.3 \mathrm{~mm} \mathrm{~h}^{-1}, 42 \%\right)$ than for nighttime irrigation events (0.07 $\left.\mathrm{mm} \mathrm{h}^{-1}\right)$. Summing up all evaluated irrigation events, the daytime ET reduction amounted $21.6 \mathrm{~mm}$ (4.3\% of the applied water) and the nighttime ET reduction amounted $1.9 \mathrm{~mm}(0.8 \%$ of the applied water). For 1 to $3 \mathrm{~h}$ after the daytime irrigation events, the ET at the moist treatment was greater (by about 12.5 to $19 \%$ on average) than the ET at the dry treatment due to the combination of gross interception losses and reduced transpiration after the irrigation. Subsequently, the $\mathrm{IL}_{\mathrm{n}}$ amounted to a total of $15.9 \mathrm{~mm}(3.1 \%$ of the applied water $)$ for all daytime irrigation events, and $6.0 \mathrm{~mm}$ (2.4\% of the applied water) for all nighttime irrigation events.

The WDEL $\mathrm{W}_{\mathrm{g}}$ during daytime irrigation $(10.9 \%)$ were greater than WDEL $\mathrm{g}$ during nighttime irrigation $(3.7 \%)$ due to the different meteorological conditions. Discounting, the ET reduction and adding the $\mathrm{IL}_{n}$, the $\mathrm{SEL}_{\mathrm{n}}$ amounted a total of 49.5 $\mathrm{mm}(9.8 \%$ of the applied water) for all daytime irrigation events, and $13.4 \mathrm{~mm}(5.4 \%$ of the applied water) for all nighttime irrigation events. Subsequently the difference 
between the WDELg and the SEL $\mathrm{W}_{\mathrm{n}}$ were modest, about $1.1 \%$ and $-1.7 \%$ of the applied water for daytime and nighttime irrigation events, respectively. Therefore the contribution of reduced evapotranspiration during sprinkler irrigation events to the water application efficiency was modest.

An evaluation of predictive equations of SELn and its components, IL $\mathrm{L}_{n}$ and WDEL $_{n}$ as a function of various meteorological variables $(\mathrm{U}, \mathrm{RH}, \mathrm{T}$ and VPD) was performed. The methodological characterization of SEL $L_{n}$ presented in this work was limited to the research field: for the WDEL $\mathrm{W}_{\mathrm{n}}$ modeling, meteorological variables used were averaged on the period 'during the irrigation', while, for $\mathrm{IL}_{\mathrm{n}}$ modeling, the meteorological values were averaged on the period 'after irrigation'. 


\section{ACKNOWLEDGEMENTS}

The authors sequence in this paper follows the "first-last-author-emphasis" norm. This research was funded by the MCINN of the Government of Spain through grants AGL2007-66716-C03-01/02, AGL2010-21681-C03-01/03; the European Commission through grant QUALIWATER (INCO-CT-2005-015031) and by the FPI-MINECO PhD grants program. The authors would like to thank the support provided by Dr. José Cavero (CSIC-EEAD), Dr. Daniel Isidoro (CITA-DGA), Dr. Steven Evett and Dr. Judy Tolk (USDA-ARS) at Bushland, TX. Thanks are particularly due to the CITA/CSIC field staff and technicians: Miguel Izquierdo, Jesus Gaudó, Juan Manuel Acín, Pilar Paniagua, Ricardo Santolaria and Eva Medina. We are also thankful for the comments by the reviewers 


\section{REFERENCES}

Allen RG, Pereira LS, Raes D, Smith M (1998) Crop evapotranspiration: guidelines for computing crop water requirements, FAO Irrigation and Drainage Paper 56. United Nations Food and Agriculture Organization, Rome.

ASAE Standard S398.1 MAR1985 (R2007) (1985) Procedure for sprinkler testing and performance reporting. In: ASAE Standards. ASAE, St. Joseph, MI.

Burt CM, Clemmens AJ, Strelkoff TS, Solomon KH, Bliesner RD, Howell TA and Eisenhauer DE (1997). Irrigation performance measures: Efficiency and uniformity. J. Irrig. Drain. Engr. 123 (6): 423-442.

Cavero J, Medina ET, Puig M, Martínez-Cob A (2009) Sprinkler irrigation changes maize canopy microclimate and crop water status, transpiration, and temperature. Agron. J. 101: 854-864.

Cavero J, Urrego YF, Fernández MV, Merino C, Martínez-Cob A (2010) Photosynthesis of maize and alfalfa during daytime sprinkler irrigation. ASA, CSSA, and SSSA International Annual Meetings: Green Revolution 2.0: Food + Energy and Environmental Security. 31 October - 3 November. Long Beach, CA, USA.

Christiansen JE (1942) Irrigation by sprinkling, California Agricultural Experimental Station Bulletin 670, University of California, Berkeley, California.

Clemmens AJ., Dedrick AR. (1994) Irrigation techniques and evaluations. In: Adv. in Agric. Sci., K. K. Tanji and Yaron, B., (Eds.). Springer-Verlag, Berlin, Germany, 64-103. 
Dastane NG (1978) Effective rainfall in irrigated agriculture. FAO Irrigation and Drainage Paper 25. FAO, Rome, Italy.

Dechmi F, Playán E, Cavero J, Faci JM, Martínez-Cob A (2003) Wind effects on solidset sprinkler irrigation depth and yield of maize (Zea mays). Irrigation Sci. 22: 67-77.

Devore J, Peck R (1986) Statistics. The Exploration and Analysis of Data. West Publishing, St Paul, MN.

De Wrachien D, Lorenzini G (2006) Modelling jet flow and losses in sprinkler irrigation: Overview and perspective of a new approach. Biosys. Engr. 94(2):297309.

Dolado J (1999) Validez de las predicciones en la estimación de costes (Validity of predictions in the cost estimate). Universidad Del Pais Vasco, Bilbao, Spain.

Du Y, Wang J, Liu, Cai C (2001) Water distribution and microclimatic effects of sprinkler irrigation on spring wheat field. Chin. J. Appl. Ecol. 12, 398-400.

Edling RJ (1985) Kinetic energy, evaporation and wind drift of droplets from low pressure irrigation nozzles. Trans. ASAE 28 (5):1543-1550.

Fritschen LJ (1960) Transpiration and evapotranspiration of maize as related to meteorological factors. U.S. Weather Bur., Res. Rept., Contract CWB-956, unpublished.

Frost KR (1963) Factors affecting evapotranspiration losses during sprinkling. Trans. ASAE 6: 282-283, 287. 
Frost KR, Schwalen HC (1960) Sprinkler evaporation losses. Agr. Engr. 36(8): 526-528.

Kohl RA, JL Wright (1974) Air temperature and vapor pressure changes caused by sprinkler irrigation. Agron. J. 66: 85-88.

Lamm F, Manges HL (2000) Partitioning of sprinkler irrigation water by a maize canopy. Trans. ASAE 43(4): 909-918.

Li J, Rao M (2000) Sprinkler water distributions as affected by winter wheat canopy. Irrig. Sci. 20, 29-35.

Lorenzini G (2004) Simpified modelling of sprinkler droplet dynamics. Biosys. Engr. 87(1): 1-11.

Martínez-Cob A (2001) Adequacy of Villalobos method to adjust eddy covariance latent heat flux. Irrig. Sci. 20: 175-188.

Martínez-Cob A (2004) Revisión de las necesidades hídricas netas de los cultivos de la Cuenca del Ebro. Internal Technical Report 2004-PH-12.I. Confederación Hidrográfica del Ebro, Zaragoza. (In Spanish).

Martínez-Cob A, Playán E, Zapata N, Cavero J, Medina ET, Puig M (2008) Contribution of evapotranspiration reduction during solid-set sprinkler irrigation to application efficiency. J. Irrig. Drain. Engr. 134: 745-756.

Martínez-Cob A, Zapata Ruiz N, Sánchez Marcos I (2010) Viento y riego: la variabilidad del viento en Aragón y su influencia en el riego por aspersión. Zaragoza, Institución "Fernando el Católico", 200p. 
McMillan WD, Burgy RH (1960) Interception loss from grass. J. Geophys. Res. 65: 2389-2394.

McNaughton KG (1981) Net interception losses during sprinkler irrigation. Agric. Meteorol. 24: 11-27.

Monteith JL (1981) Evaporation and surface temperature. Q. J. R. Meteorol. Soc., 107, 1-27.

Norman E, Joyce R, Whittaker M (1990) Advanced design and technology. Third ed. Longman, Harlow, Essex.

Norman JM, Campbell GS (1983) Application of the plant environment model to problems in irrigation, In: Adv. in Irrig. 2: 155-188. New York, N.Y.: Academic Press, Inc.

Playán E, Salvador R, Faci JM, Zapata N, Martínez-Cob A, Sánchez I (2005) Day and night wind drift and evaporation losses in sprinkler solid-sets and moving laterals. Agric. Water Manage. 76 (3): 139-159.

Playán E, Zapata N, Faci JM, Tolosa D, Lacueva JL, Pelegrin J, Salvador R, Sánchez I, Lafita A (2006) Assessing sprinkler irrigation uniformity using a ballistic simulation model. Agric. Water Manage. 84 (1-2): 89-100.

Robinson FE (1970) Modifying an arid microclimate with sprinklers. Agric. Engr. $51: 465$.

Sánchez I, Zapata N, Faci JM (2010a) Combined effect of technical, meteorological and agronomical factors on solid-set sprinkler irrigation: I. Irrigation 
performance and soil water recharge in alfalfa and maize. Agric. Water Manage. 97(10): 1571-1681.

Sánchez I, Zapata N, Faci JM (2010b) Combined effect of technical, meteorological and agronomical factors on solid-set sprinkler irrigation: II. Modifications of the wind velocity and of the water interception plane by the crop canopy. Agric. Water. Manage. 97(10): 1591-1601.

Sánchez I, Zapata N, Faci JM, Martinez-Cob A (2011) The spatial variability of the wind in a sprinkler irrigated district: Implications for irrigation management. Biosys. Engin. 109(1): 65-76.

Schneider AD, Howell T A (1995) Reducing sprinkler water losses. In Proc. Central Plains Irrigation Shortcourse, Garden City, Kans., 7-8 Feb 1995, 60-63. Manhattan, Kans.: Biological and Agricultural Engineering, Kansas State University.

Seginer I (1967) Net losses in sprinkler irrigation. Agric. Meteorol. 4, 281-291.

Smajstrla AG, Hanson RS (1980) Evaporation effects on sprinkler irrigation efficiencies. Proc. Soil \& Crop Sci. Soc. Florida 39: 28-33.

Soil Survey Staff (1999) Soil taxonomy Agriculture Handbook 436, 2nd Ed., Natural Resources Conservation Service, USDA, Washington, D.C.

Solomon KH, Kincaid DC, Bezdek JC (1985) Drop size distribution for irrigation spray nozzles. Trans. ASAE 28(6): 1966-1974.

Steiner JL, Kanemasu ET, Clark RN (1983a) Spray losses and partitioning of water under a center pivot sprinkler system. Trans. ASAE 26: 1128-1134. 
Steiner JL, Kanemasu ET, Hasza D (1983b) Microclimatic and crop responses to center pivot sprinkler and to surface irrigation. Irrig. Sci. 4:201-214.

Sternberg YM (1967) Analysis of sprinkler irrigation losses. J. Irrig. and Drain. Div. (ASCE) 93(IR4): 111-124.

Tarjuelo JM, Ortega JF, Montero J, de Juan JA (2000) Modelling evaporation and drift losses in irrigation with medium size impact sprinklers under semi-arid conditions. Agric. Water Manag. 43: 263-284.

Thompson AL, Gilley JR, Norman JM (1993a) A sprinkler water droplet evaporation and plant canopy model: I. Model development, Trans. ASAE 36(3), 735-741.

Thompson AL, Gilley JR, Norman JM (1993b) A sprinkler water droplet evaporation and plant canopy model: II. Model application. Trans. ASAE 36(3): 743-750.

Thompson AL, Martin DL, Norman JM, Howell TA (1996) Scheduling effects on evapotranspiration with overhead and below canopy application. In proceedings of the international conference Evapotranspiration and Irrigation Scheduling, 3-6 Nov. 1996, 182-188. St. Joseph, Mich.: ASAE.

Tolk JA, Howell TA, Evett, SR (2006) Nighttime evapotranspiration from alfalfa and cotton in a semiarid climate. Agron. J. 98:730-736. doi:10.2134/agronj2005.0276.

Tolk JA, Howell TA, Steiner JL, Krieg DR, Schneider AD (1995) Role of transpiration suppression by evaporation of intercepted water in improving irrigation efficiency. Irrig. Sci. 16: 89-95. 
Waggoner PE, Begg JE, Turner NC (1969) Evaporation of dew. Agric. Meterol., 6, 227-230.

Wilcox BP, Rawls WJ, Brakensiek DL, Wight JR (1990) Predicting runoff from rangeland catchments: A comparison of two models. Water Resour. Res. 26(10):2401-2410.

Willmott CJ (1981) On the validation of models. Phys. Geog. 2:184-194

Yazar A (1984) Evaporation and drift losses from sprinkler irrigation systems under various operating conditions. Agric. Water Manage. 8:439-449.

Yonts CD (2000) Performance of In-Canopy Sprinklers. Proceedings of Central Plains Irrigation Short Course and Exposition. February 9-10, 2000, Garden City, Kansas. Central Plains Irrigation Association, Colby, Kansas. pp.107-112.

Zapata N, Playán E, Martínez-Cob A, Sánchez I, Faci JM, Lecina S (2007) From onfarm solid-set sprinkler irrigation design to collective irrigation network design in windy areas. Agric. Wat. Manage. 87 (2): 187-199. 


\section{LIST OF TABLES}

Table 1: General characteristics of the 36 evaluated irrigation events: irrigation events number $(N)$, average irrigation time per event (h), irrigation depth $(\mathrm{mm}), U\left(\mathrm{~m} \mathrm{~s}^{-1}\right)$ at $2 \mathrm{~m}$ above ground level, air temperature $\left({ }^{\circ} \mathrm{C}\right)$ and vapor pressure deficit $(\mathrm{kPa})$. Minimum and maximum values are between parentheses.

\begin{tabular}{ccccccc}
\hline $\begin{array}{c}\text { Irrigation } \\
\text { events }\end{array}$ & $\mathrm{N}$ & $\begin{array}{c}\text { Irrigation } \\
\text { Time (h) }\end{array}$ & $\begin{array}{c}\text { Irrigation } \\
\text { Depth }(\mathrm{mm})\end{array}$ & $\begin{array}{c}\mathrm{U}(\mathrm{a}) \\
\left(\mathrm{m} \mathrm{s}^{-1}\right)\end{array}$ & $\begin{array}{c}\mathrm{T}(\mathrm{a}) \\
\left({ }^{\circ} \mathrm{C}\right)\end{array}$ & $\begin{array}{c}\mathrm{VPD}^{(\mathrm{a})} \\
(\mathrm{kPa})\end{array}$ \\
\hline $\begin{array}{c}\text { Daytime } \\
\text { Irrigations }\end{array}$ & 24 & 2.7 & 21.1 & 2.5 & 24.4 & 1.47 \\
$\begin{array}{c}\text { Nighttime } \\
\text { Irrigations }\end{array}$ & 12 & $(1.8-4)$ & $(13.7-31.3)$ & $(0.6-5.8)$ & $(15.6-32.2)$ & $(0.52-4.36)$ \\
$\begin{array}{c}\text { All } \\
\text { Irrigations }\end{array}$ & \multirow{2}{*}{36} & $(1.2-4)$ & $(8.9-32.9)$ & $(0.2-3.1)$ & $(7.5-18.8)$ & $(0.06-0.52)$ \\
\hline
\end{tabular}

(a) Recorded at the 'grass' weather station 
Table 2. Average total daytime and nighttime evapotranspiration of moist (ET $\left.T_{M T}\right)$ and dry (ET $\left.T_{D T}\right)$ treatments during 2009 irrigation season, and average differences $E T_{D T}-E T_{M T}$ during, 1-2 hours before and 1-3 hours after the irrigation event.

\begin{tabular}{|c|c|c|c|c|c|c|c|c|c|}
\hline \multirow[b]{2}{*}{ Perio } & & \multicolumn{4}{|c|}{ Daytime irrigation } & \multicolumn{4}{|c|}{ Nighttime irrigation } \\
\hline & & $\mathrm{N}$ & $\begin{array}{c}\mathrm{ET}_{\mathrm{DT}} \\
\left(m m h^{-1}\right)\end{array}$ & $\begin{array}{c}\mathrm{ET}_{\mathrm{MT}} \\
\left(m m h^{-1}\right)\end{array}$ & $\begin{array}{c}\mathrm{ET}_{\mathrm{DT}}-\mathrm{ET}_{\mathrm{MT}} \\
\left(m m h^{-1}\right)\end{array}$ & $\mathrm{N}$ & $\begin{array}{c}\mathrm{ET}_{\mathrm{DT}} \\
\left(m m h^{-1}\right)\end{array}$ & $\begin{array}{c}\mathrm{ET}_{\mathrm{MT}} \\
\left(m m h^{-1}\right)\end{array}$ & $\begin{array}{c}\mathrm{ET}_{\mathrm{DT}}-\mathrm{ET}_{\mathrm{MT}} \\
\left(m m h^{-1}\right)\end{array}$ \\
\hline \multirow{2}{*}{ Before } & $1 \mathrm{~h}$ & 24 & 0.44 & 0.42 & $0.02^{\mathrm{ns}}$ & 12 & 0.00 & 0.01 & $-0.010^{n s}$ \\
\hline & $2 \mathrm{~h}$ & 24 & 0.27 & 0.31 & $-0.04^{\mathrm{ns}}$ & 12 & 0.07 & 0.06 & $0.012^{\text {ns }}$ \\
\hline \multirow[t]{2}{*}{ During } & & 24 & 0.70 & 0.41 & $0.29 \mathrm{~s}$ & 12 & 0.01 & -0.07 & $0.074^{\mathrm{s}}$ \\
\hline & $1 \mathrm{~h}$ & 24 & 0.71 & 0.82 & $-0.11^{\mathrm{s}}$ & 12 & 0.17 & 0.24 & $-0.080^{\mathrm{s}}$ \\
\hline \multirow[t]{2}{*}{ After } & $2 \mathrm{~h}$ & 24 & 0.64 & 0.72 & $-0.08^{s}$ & 12 & 0.34 & 0.35 & $-0.009 \mathrm{~ns}$ \\
\hline & $3 \mathrm{~h}$ & 24 & 0.52 & 0.62 & $-0.09 \mathrm{~s}$ & 12 & 0.45 & 0.45 & $-0.002^{n s}$ \\
\hline
\end{tabular}


Table 3. Gross wind drift and evaporation losses (WDEL $\left.L_{g}\right)$, evapotranspiration reductions during irrigation $\left(E T_{D T}-E T_{M T}\right)_{d i}$ net wind and evaporation losses (WDEL $\left.L_{n}\right)$, net intercepted losses (IL $\left.L_{n}\right)$ and net sprinkler losses $\left(S E L_{n}\right)$ for the evaluated irrigation events.

\begin{tabular}{|c|c|c|c|c|c|c|c|c|c|c|c|c|c|}
\hline \multirow[t]{2}{*}{ Irrigation } & \multirow[t]{2}{*}{ Events } & \multirow[t]{2}{*}{$N$} & \multirow{2}{*}{$\begin{array}{c}I_{g} \\
(\mathrm{~mm})\end{array}$} & \multicolumn{2}{|c|}{$W D E L_{g}$} & \multicolumn{2}{|c|}{$\begin{array}{l}\left(E T_{D T^{-}}\right. \\
\left.E T_{M T}\right)_{d i}\end{array}$} & \multicolumn{2}{|c|}{$W D E L_{n}$} & \multicolumn{2}{|c|}{$I L_{n}$} & \multicolumn{2}{|c|}{$S E L_{n}$} \\
\hline & & & & $(\mathrm{mm})$ & $(\%)$ & $(\mathrm{mm})$ & $(\%)$ & $(\mathrm{mm})$ & $(\%)$ & $(\mathrm{mm})$ & $(\%)$ & $(\mathrm{mm})$ & $(\%)$ \\
\hline \multirow{2}{*}{ Daytime } & Average & \multirow{2}{*}{24} & 21.1 & 2.3 & \multirow{2}{*}{10.9} & 0.9 & \multirow{2}{*}{4.3} & 1.4 & \multirow{2}{*}{6.6} & 0.7 & \multirow{2}{*}{3.1} & 2.1 & \multirow{2}{*}{9.8} \\
\hline & Total & & 507.1 & 55.3 & & 21.6 & & 33.7 & & 15.9 & & 49.5 & \\
\hline \multirow{2}{*}{ Nighttime } & Average & \multirow{2}{*}{12} & 20.9 & 0.8 & \multirow{2}{*}{3.7} & 0.1 & \multirow{2}{*}{0.8} & 0.6 & \multirow{2}{*}{3.0} & 0.5 & \multirow{2}{*}{2.4} & 1.1 & \multirow{2}{*}{5.4} \\
\hline & Total & & 250.3 & 9.3 & & 1.9 & & 7.4 & & 6.0 & & 13.4 & \\
\hline \multirow{2}{*}{$\begin{array}{c}\text { All } \\
\text { Irrigations }\end{array}$} & Average & \multirow[t]{2}{*}{36} & 21.0 & 1.8 & \multirow[t]{2}{*}{8.5} & 0.7 & \multirow[t]{2}{*}{3.1} & 1.1 & \multirow[t]{2}{*}{5.4} & 0.6 & \multirow[t]{2}{*}{2.9} & 1.8 & \multirow[t]{2}{*}{8.3} \\
\hline & Total & & 757.4 & 64.6 & & 23.5 & & 41.1 & & 21.9 & & 62.9 & \\
\hline
\end{tabular}




\section{LIST OF FIGURES}

Figure 1. Scheme of experimental plot: (WDEL $L_{g}$ location of measurement of wind drift and evaporation losses and uniformity coefficient; (Lys) weighing lysimeters; (Met) automatic meteorological stations; (Pres) irrigation pressure transducers; (Sp) sprinklers; (ICH) irrigation control hut; $(C c)$ catch cans.

Figure 2. Air temperature (T), Canopy temperature and Vapor pressure deficit (VPD) measured at the two treatments, moist (MT) and dry (DT), for 1-2 hours before, during and 1-3 hours after irrigation for daytime (left figure) and nighttime (right figure) irrigation events. Each value on the continuous line curves represents the average for all irrigations events lasting 3 hours.

Figure 3. Air Temperature, Canopy Temperature and VPD values during one daytime (left) and one nighttime (right) sprinkler irrigation event at the moist treatment versus corresponding rates recorded at the dry treatment, regressions lines and equations were presented. Dashed lines correspond to the 1:1 lines.

Figure 4. Average alfalfa evapotranspiration rates (ET) 1-2 $\mathrm{h}$ before, during, and 1-3 $\mathrm{h}$ after daytime sprinkler irrigation events at the moist treatment (MT) versus corresponding rates recorded at the dry treatment (DT).

Figure 5. Net intercepted Losses ( $\left.I L_{n}\right)$ calculated after all irrigation events (daytime and nighttime) versus the vapor pressure deficit $(V P D)$. The $I L_{n}$ were cumulative values until no difference between treatments was observed ( 1 to 3 h after the irrigation event). The VPD was recorded at the 'grass station' and averaged for the same period of time.

Figure 6. Net sprinkler evaporation losses $\left(S E L_{n}\right)$ calculated for all irrigation events (daytime and nighttime) versus the wind speed $(U) . U$ was recorded at the 'grass station' and averaged for the periods during and after ( 1 to $3 h$ ) the irrigation events. 
Figure 1. Scheme of experimental plot: (WDEL $\left.L_{g}\right)$ location of measurement of wind drift and evaporation losses and uniformity coefficient; (Lys) weighing lysimeters; (Met) automatic meteorological stations; (Pres) irrigation pressure transducers; (Sp) sprinklers; (ICH) irrigation control hut; (Cc) catch cans. 

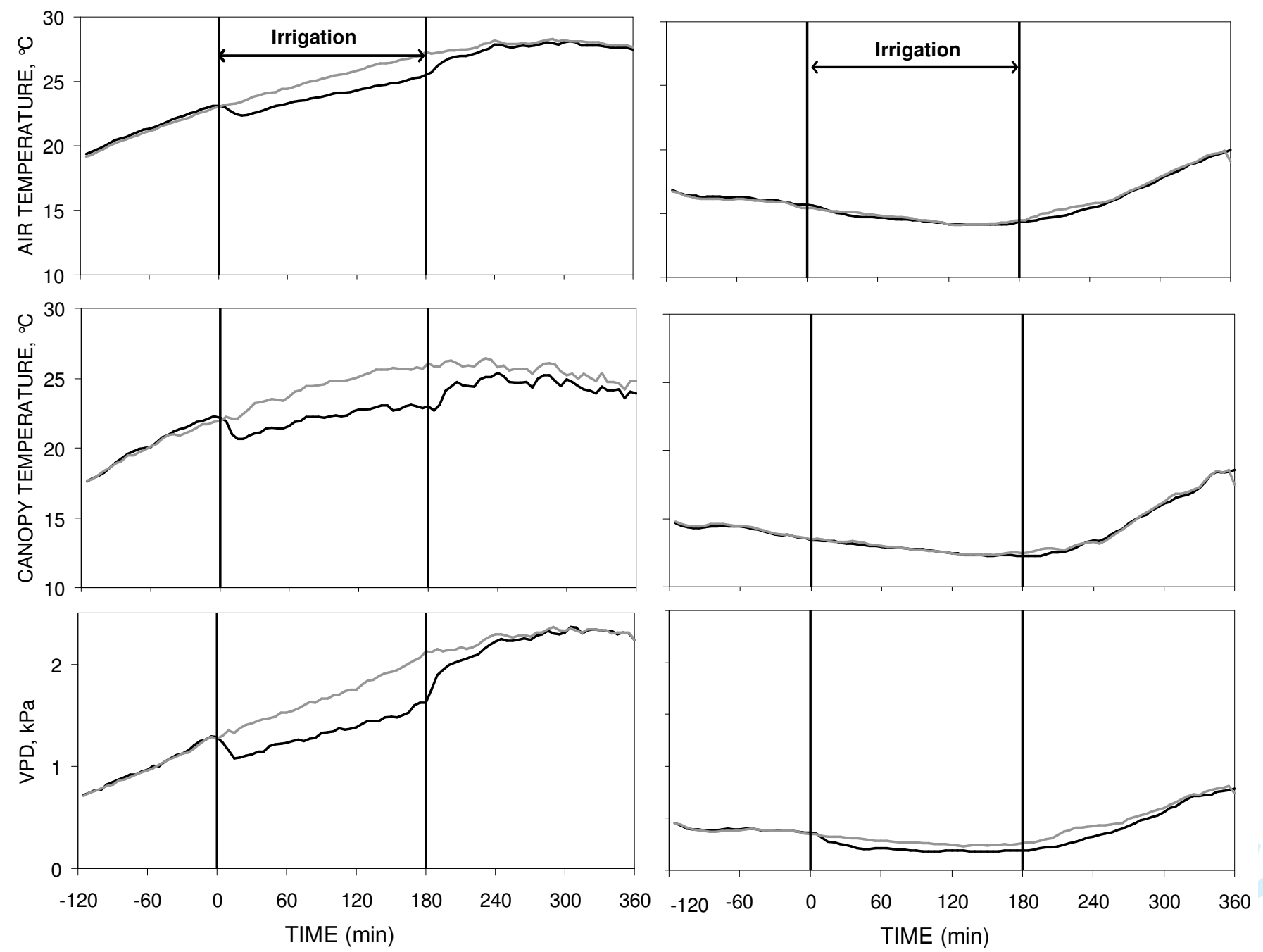

\begin{tabular}{|c|c|c|c|}
\hline - MT & —DT & $\times \quad \mathrm{SDT}(\mathrm{MT})$ & $\Delta \mathrm{SDT}(\mathrm{DT})$ \\
\hline
\end{tabular}

Figure 2. Air temperature (T), Canopy temperature and Vapor pressure deficit (VPD) measured at the two treatments, moist (MT) and dry (DT), for 1-2 hours before, during and 1-3 hours after irrigation for daytime (left figure) and nighttime (right figure) irrigation events. Each value on the continuous line curves represents the average for all irrigations events lasting 3 hours. 
1

2

3

4

5

6

7

8

9

10

11

12

13

14

15

16

17

18

19

20

21

22

23

24

25

26

27

28

29

30

31

32

33

34

35

36

37

38

39

40

41

42

43

44

45

46

47

48

49

50

51

52

53

54

55

56

57

58

59

60
Daytime irrigation
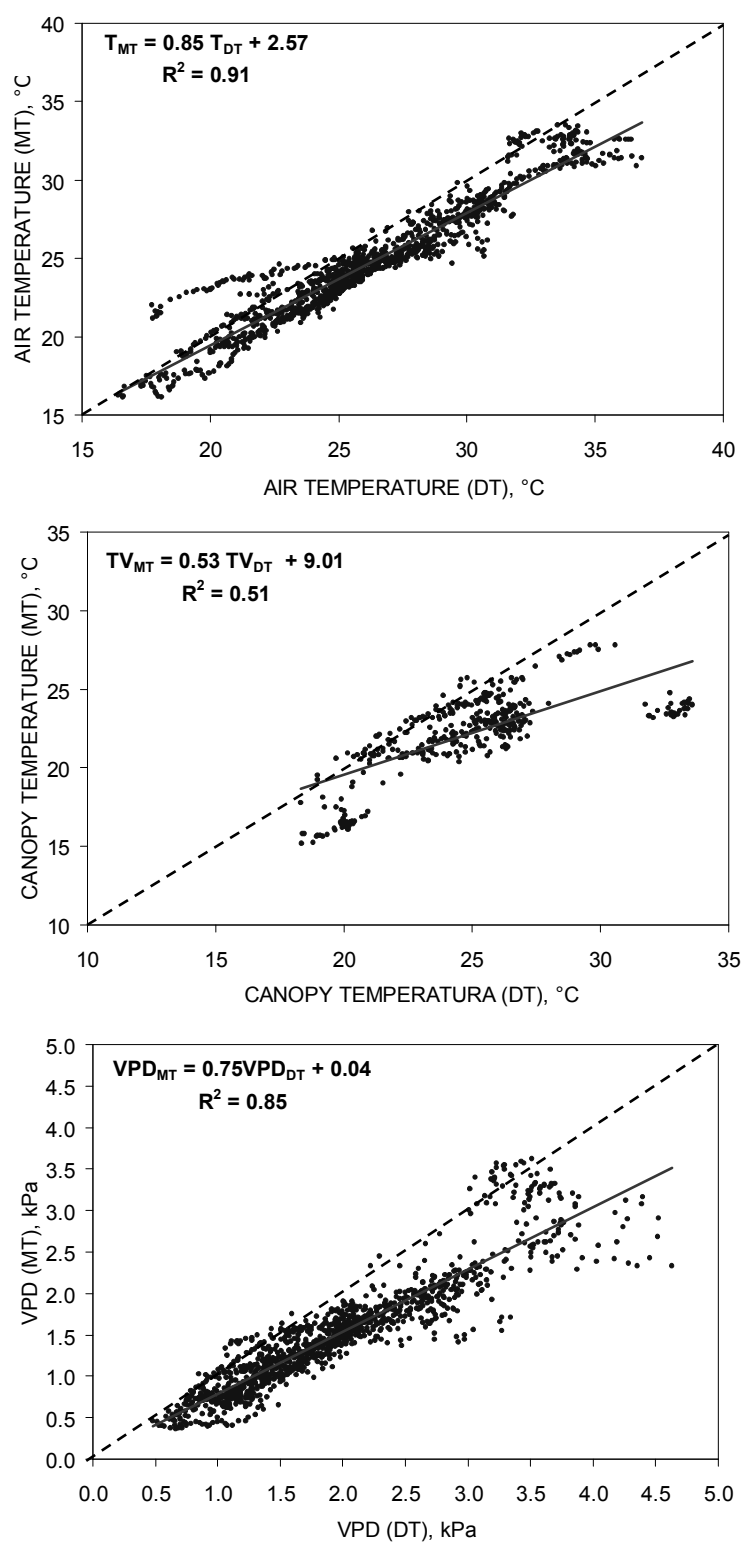

- Ir $\quad-=1: 1 \longrightarrow$ Regr
Nighttime irrigation
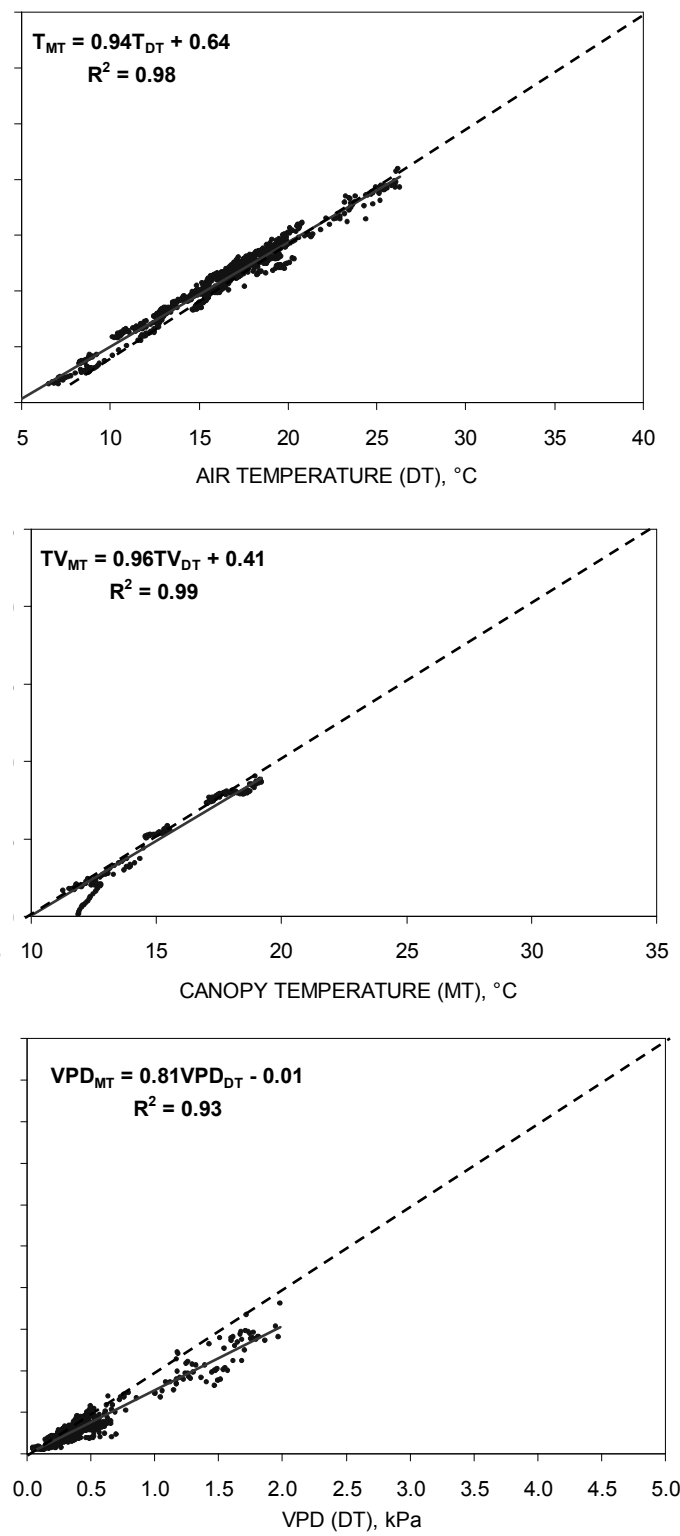

Figure 3: 5-min Air Temperature, Canopy Temperature and VPD values during daytime (left) and nighttime (right) sprinkler irrigation events at the moist treatment versus corresponding rates recorded at the dry treatment, regressions lines and equations were presented. Dashed lines correspond to the 1:1 lines. 

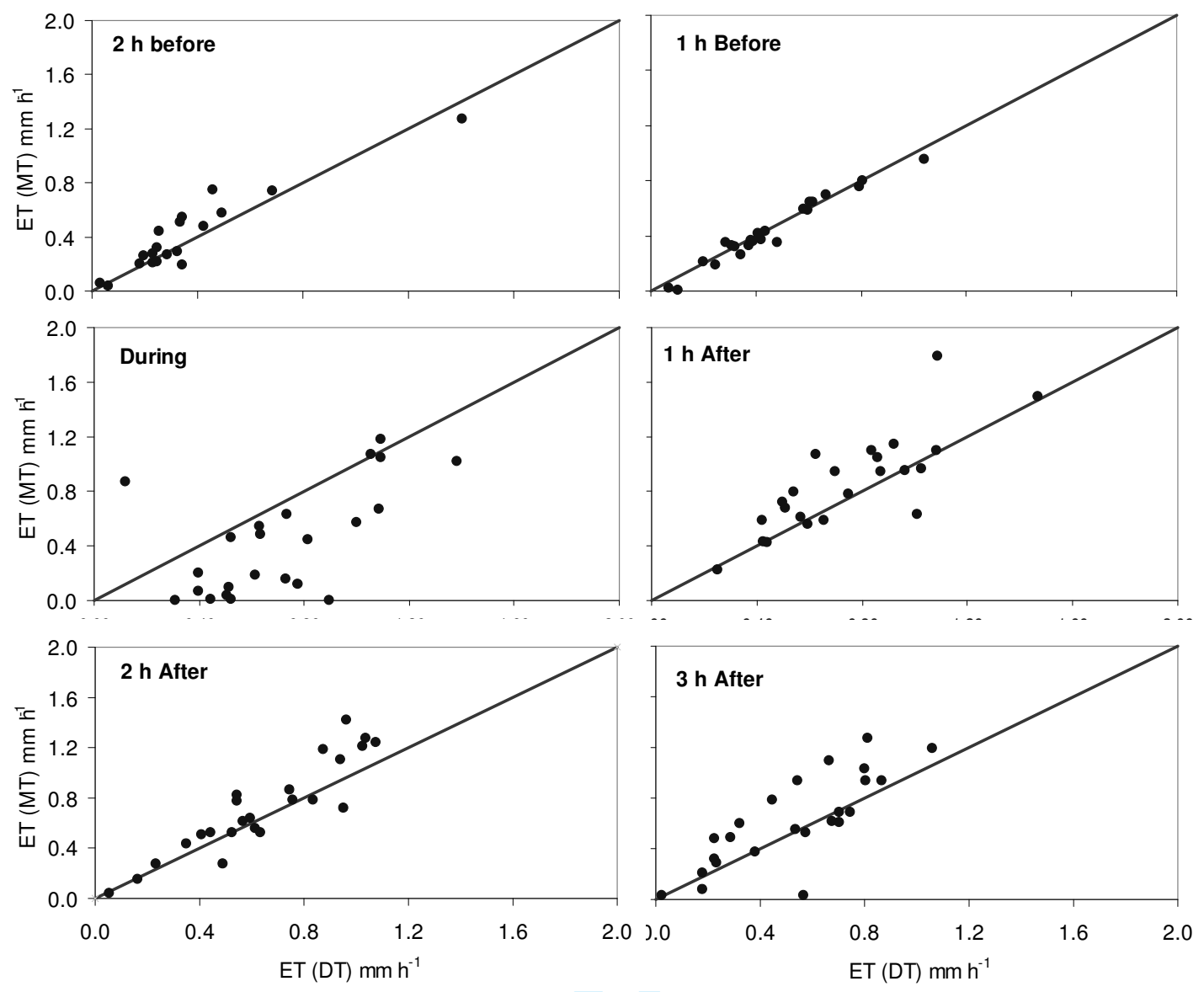

Figure 4. Average alfalfa evapotranspiration rates (ET) $1-2 \mathrm{~h}$ before, during, and $1-3 \mathrm{~h}$ after daytime sprinkler irrigation events at the moist treatment (MT) versus corresponding rates recorded at the dry treatment (DT). 


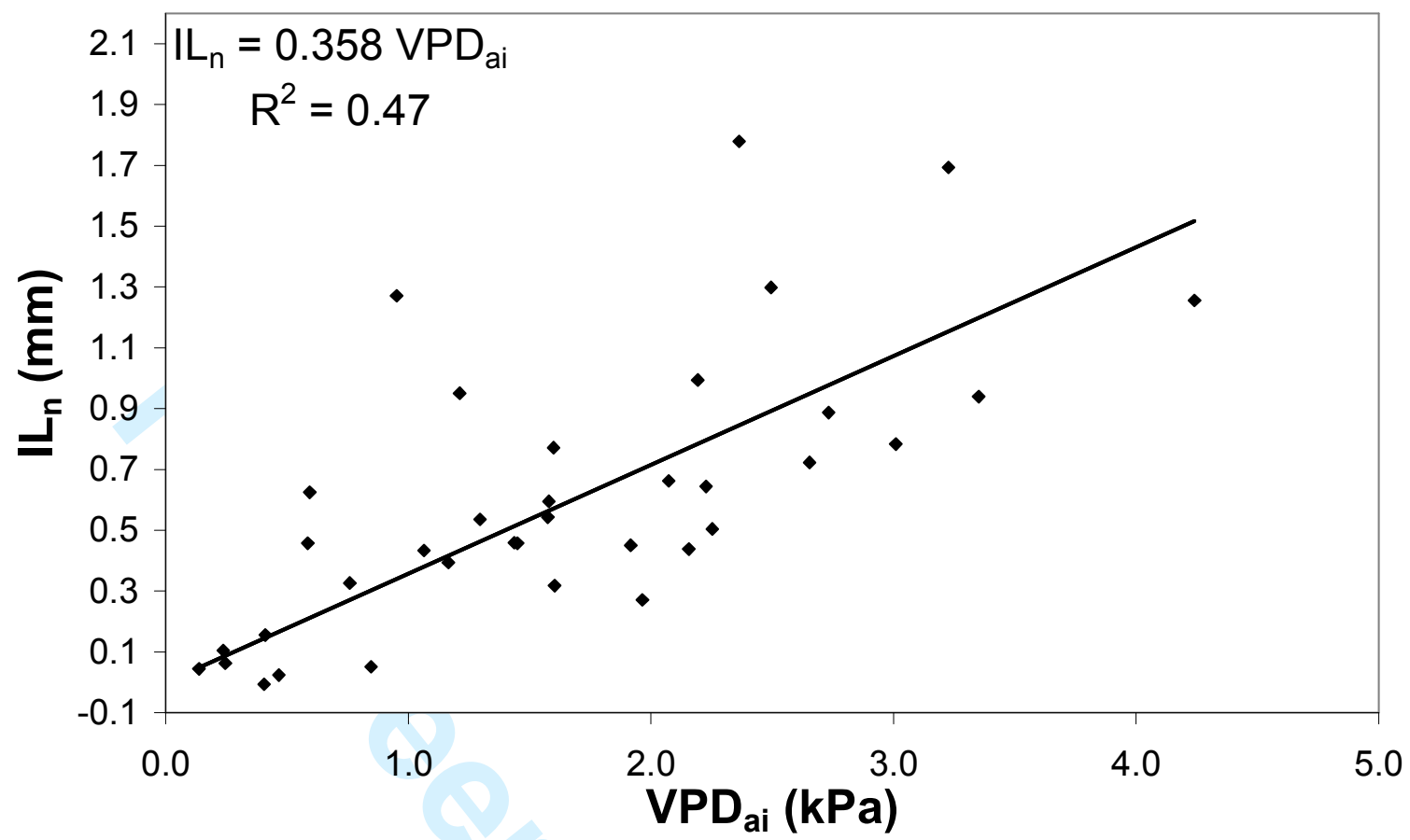

Figure 5. Net intercepted Losses ( $\left.I L_{n}\right)$ calculated after all irrigation events (daytime and nighttime) versus the vapor pressure deficit (VPD). The $I L_{n}$ were cumulative values until no difference between treatments was observed (1 to $3 \mathrm{~h}$ after the irrigation event).The VPD was recorded at the 'grass station' and averaged for the same period of time. 


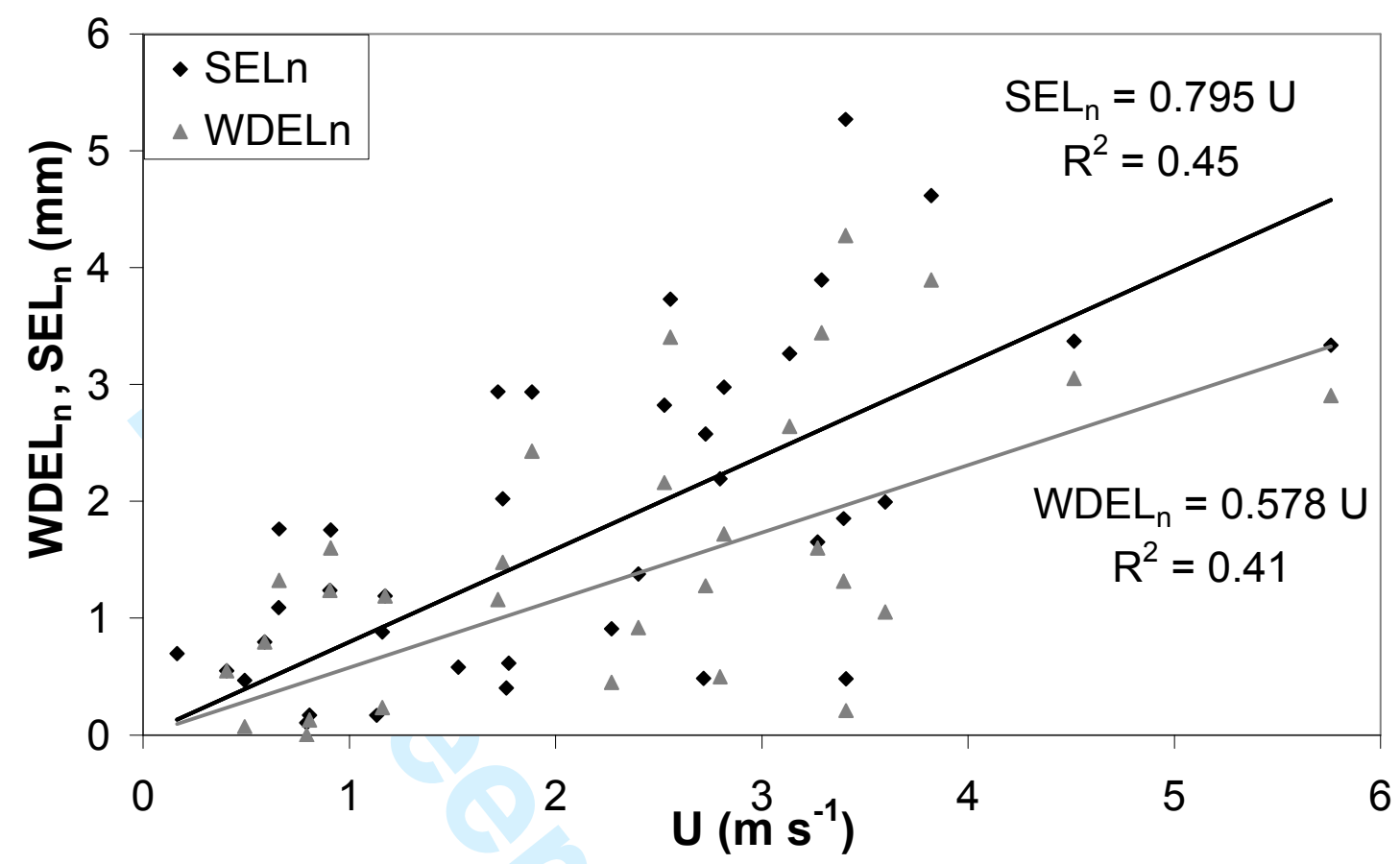

Figure 6. Net sprinkler evaporation losses (SELn) calculated for all irrigation events (daytime and nighttime) versus the wind speed $(U)$. U was recorded at the 'grass station' and averaged for the periods during and after (1 to $3 \mathrm{~h}$ ) the irrigation events. 